\title{
Recurrent respiratory infections in elderly
}

\author{
B Brescia \\ From de Senectute: Age and Health Forum \\ Catanzaro, Italy. 5-7 December 2009
}

The physiological aging of the respiratory apparatus and the prolongued exposure to harmful agents, spread by the ventilation, cause the remodeling of the osteo-cartilagineous tissue and the hypertrophy of the nasal mucosa; these pathological changes alter the mechanism of defense and above all compromise the muco-ciliary clearance.

Bacteria are in great measure hygroscopic, so once they are carried in the respiratory tract, they tend to increase their volume and became more susceptible to phagocytosis. Although the macrophage activity is preserved, IgM concentration progressively tends to decrease, therefore reducing the primary response to infection and inducing a decline of cell-mediated immunity.

All the normal mucosal secretions contain iron binding protein. The availability of this element powers the virulence of many microorganisms. The host responds with the release of transferrin trying to remove iron from the invading organisms. This mechanism is completely absent in the elderly.

In the older population the incidence of respiratory tract infection is higher that in the younger. Often, the bacteria involved in the infection are not easy to be dectect. The material which can be used to isolate the microorganism can be the expectorated mucus or the mucus aspirated from bronchi. Further more, 'mixed infections', caused by the presence of both viruses and bacteria, complicate the primary isolation

Comparing the difference between outpatients' and inpatients' infections agents, we have noticed an increased prevalence of multi-bacterial infection in hospitalized patients. Patients often report that they have tried multiple antibiotic therapies, without clinical response, before the isolation practised during hospitalization; this practice reflects on the isolated strain and causes antibiotic resistances

Cosenza Hospital, Italy
It's very interesting to study the trend of TB infection in the elder patients. It is worth noting that the TB infection usually has a bimodal performance. The first peak in the third decade of life and the second in the sixth decade. Both the infection and the endogenous reinfection can appear. In cohabitation with children, problems are exacerbated more by viral than by bacterial agents.

Finally, the choice of the better antibiotic therapy, characterized by clinical benefits and minimal side effects, is driven by the patient conditions, the severity of the infection, the identification (certain or presumed) of the responsible micro-organism and the way of administration which can offer a safe and rapid bioavailability.

Published: 19 May 2010

doi:10.1186/1471-2318-10-S1-L20

Cite this article as: Brescia: Recurrent respiratory infections in elderly. BMC Geriatrics 2010 10(Suppl 1):L20.

Submit your next manuscript to BioMed Central and take full advantage of:

- Convenient online submission

- Thorough peer review

- No space constraints or color figure charges

- Immediate publication on acceptance

- Inclusion in PubMed, CAS, Scopus and Google Scholar

- Research which is freely available for redistribution

Submit your manuscript at www.biomedcentral.com/submit 